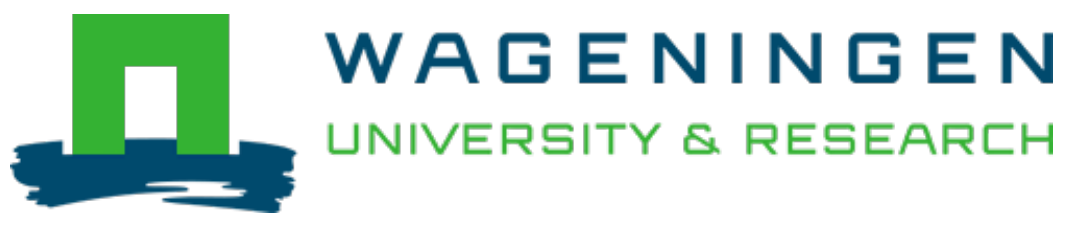

\title{
The effect of cowpea supplementation on the quality of kenkey, a traditional Ghanaian fermented maize food.
}

\author{
Journal of Cereal Science \\ Nche, P.F.; Nout, M.J.R.; Rombouts, F.M. \\ https://doi.org/10.1006/jers.1994.1026
}

This publication is made publicly available in the institutional repository of Wageningen University and Research, under the terms of article $25 \mathrm{fa}$ of the Dutch Copyright Act, also known as the Amendment Taverne. This has been done with explicit consent by the author.

Article 25 fa states that the author of a short scientific work funded either wholly or partially by Dutch public funds is entitled to make that work publicly available for no consideration following a reasonable period of time after the work was first published, provided that clear reference is made to the source of the first publication of the work.

This publication is distributed under The Association of Universities in the Netherlands (VSNU) 'Article $25 \mathrm{fa}$ implementation' project. In this project research outputs of researchers employed by Dutch Universities that comply with the legal requirements of Article $25 \mathrm{fa}$ of the Dutch Copyright Act are distributed online and free of cost or other barriers in institutional repositories. Research outputs are distributed six months after their first online publication in the original published version and with proper attribution to the source of the original publication.

You are permitted to download and use the publication for personal purposes. All rights remain with the author(s) and / or copyright owner(s) of this work. Any use of the publication or parts of it other than authorised under article $25 \mathrm{fa}$ of the Dutch Copyright act is prohibited. Wageningen University \& Research and the author(s) of this publication shall not be held responsible or liable for any damages resulting from your (re)use of this publication.

For questions regarding the public availability of this publication please contact openscience.library@wur.nl 


\title{
The Effect of Cowpea Supplementation on the Quality of Kenkey, a Traditional Ghanaian Fermented Maize Food
}

\author{
P. F. Nche, M. J. R. Nout* and F. M. Rombouts \\ Agricultural University, Department of Food Science, Bomenweg 2, 6703 HD Wageningen, \\ The Netherlands
}

Received 25 January 1993

\begin{abstract}
The cffects were evaluated of cowpca-mediated protcin cnrichment on factors relating to kenkcy acceptability. Kenkey was prepared on a laboratory scale from a $4: 1$ mixture of maize (Zea mays) and red or white cowpea (Vigna unguiculata) and compared with an all-maize product in terms of parameters such as the fermentation profile of doughs, colour and fracture profiles. There was no significant difference between the fermentation profiles after 4 days' fermentation at $30^{\circ} \mathrm{C}$, with final dough $\mathrm{pH}$ values reaching 4.07 and 4.08 for all-maize and maize/cowpca mixtures, respectively. Addition of wholegrain cowpeas resulted in an increase in the crude protein content to $12.99 \%(\mathrm{w} / \mathrm{w}$ ) and $13.89 \%$ (w/w; dry weight basis) for kenkey supplemented with $20 \%$ white and $20 \%$ red cowpea, respectively, compared with $10.80 \%(\mathrm{w} / \mathrm{w})$ for unsupplemented kenkey. Addition of cowpea reduced the whiteness (Hunter $\mathrm{L}$ value) of the kenkey by $12 \%$ (using white cowpeas) and by $27 \%$ (using red cowpeas). The use of dehulled red cowpeas improved the whiteness only slightly. Cowpeasupplemented kenkey was more homogeneous and less prone to fracture than all-maize kenkey. The force required to fracture cowpea-supplemented kenkey was higher than for traditional kenkey, and increased with increasing cowpea concentrations. Kenkey stored for 24 hours required over twice as much force to fracture than freshly prepared kenkey. A group of native Ghanaians familiar with the traditional maize kenkey sampled the new product and confirmed that kenkey made from a mixture of wholegrain white cowpea or dehulled red cowpea and maize compared very well with the traditional kenkey.
\end{abstract}

\section{INTRODUCTION}

Kenkey, a dumpling made from fermented maize dough, is a popular staple amongst the people of Ghana. There are several types of kenkey (ga, fanti), but the processing methods are largely similar. In the traditional kenkey process ${ }^{1,2}$, maize is cleaned and then stecped for 1 to 2 days. The steep water is drained and the grain coarsely milled and made into a dough by adding water $(1: 3 ; \mathrm{v} / \mathrm{w})$. The dough is then left to ferment naturally in a heaped mass or in covered containers for 2 to 3 days. The fermented dough is then divided into two equal parts, one of which is slurried and cooked to gelatinisation. This gives a sticky paste which is then mixed with the

\footnotetext{
* To whom correspondence should be addressed.
}

uncooked part to give a kneadable dough called the aflata. Balls of appropriate size $(\approx 500 \mathrm{~g})$ are shaped, wrapped (in corn sheaths for ga kenkey or banana leaves for fanti kenkey). Salt is also added to dough for ga kenkey before shaping and wrapping. The wrapped dumplings are immersed in water and boiled in a drum or large iron pot for 2 to 3 hours.

Since maize is the basic raw material, such products are rich in carbohydrate, relatively low in protein and deficient in some essential amino acids, particularly lysine. In a region where animal sources of protein are often in short supply, plant sources such as legumes may be of immense importance. Attempts have been made, with some success, at improving the protein quality and quantity of traditional maize-based fermented products of Ghana ${ }^{3}$ and Nigeria ${ }^{4}$ by supplemen- 
tation with soya beans. Soya beans are rather expensive, however, and are not well known in West African households. Being relatively cheaper and more readily available, cowpeas may provide a suitable alternative to the more expensive soya beans ${ }^{5}$. In this work, cowpeas were used as a protein supplement to the traditional allmaize Ghanaian kenkey. This improves both protein quantity and protein quality since the methionine-containing maize is complemented by the lysine-containing cowpeas ${ }^{6}$ providing a better balance of amino acids, especially cssential amino acids.

In this research, the rate of fermentation, the colour and textural properties, as well as the overall acceptability, of cowpea-supplemented kenkey were compared with the conventional allmaize formula.

\section{EXPERIMENTAL}

Maize (Zea mays cv. Obaatanba) and red and white cowpeas (Vigna unguiculata crs Benpla and Asontem, respectively) were obtained from the Crops Research Institute, CSIR, Kwadaso, Ghana. Whole grain and dehulled cowpeas were used. Dehulling was done by hand following $48 \mathrm{~h}$ of soaking in excess water.

\section{The laboratory kenkey process}

In the laboratory process (Fig. 1), maize or a $4: 1$ mixture of maize and cowpea $(0.5-1.0 \mathrm{~kg})$ was soaked for $48 \mathrm{~h}$ in tap water (approx. 31). The soak water was drained and the grain coarsely ground in a hammer mill (Fritsch Pulverisette, Type 14.702, Marius Instruments, Utrecht, The Netherlands) with rotor and sieve no. 4 and made into a dough, $\mathbf{M}_{0}, \mathrm{Mw}_{0}$ or $\mathrm{Mr}_{0}$, from maize, maize/white cowpea or maize/red cowpea, respectively, by adding water $(1: 3 ; \mathrm{v} / \mathrm{w})$. The dough was then placed in a 1-1 beaker, covered with polyethylene film and allowed to ferment naturally for a standard 4 days at $30^{\circ} \mathrm{C}$. The fermented dough, $\mathrm{M}_{4}, \mathrm{Mw}_{4}$ or $\mathrm{Mr}_{4}$, was then divided into two equal portions, one of which was slurried with water $(3: 1 ; \mathrm{v} / \mathrm{w} ;$ dry weight basis) and stir-cooked to gelatinization to give the aflata. The cooked and uncooked portions were mixed, kneaded and dumplings were made and wrapped, first in polyethylene film followed by aluminium foil, as direct contact with aluminium foil resulted in darkening of the foil during cooking, imparting a black colour to the outside of the dumpling. The wrapped dumplings were immersed in boiling water to cook. Dumplings were smaller $(250-300 \mathrm{~g})$ than in the traditional household process, hence the cooking time (under constant heat in a covered saucepan) was reduced to $1 \mathrm{~h}$. The resulting products were allmaize $\left(\mathrm{M}_{4} \mathrm{C}_{\mathrm{I}}\right)$, white cowpea-supplemented $\left(\mathrm{Mw}_{4} \mathrm{C}_{1}\right)$ and red cowpea-supplemented $\left(\mathrm{Mr}_{4} \mathrm{C}_{1}\right)$ kenkeys.

\section{Fermentation profile}

During the 4 days of fermentation, the microbial count, pH, and titratable acidity (per cent lactic acid) were determined ${ }^{7}$ on a daily basis. Counts were made of the functional groups of microorganisms in the product, namely lactic acid bacteria $(\mathrm{LAB})$ and yeasts. In addition, Enlerobacteriaceae were monitored for public health reasons. Lactic acid bacteria were counted in MRS agar (Merck 10661) pour plates containing $0 \cdot 1 \%(\mathrm{w} / \mathrm{v})$ Natamycin ('Delvocid', Gist-brocades, Delft, The Netherlands) overlaid with MRS agar without Delvocid, the yeasts in Oxytetracycline Glucose Yeast Extract agar (Oxoid CM 545) containing $0.01 \%(\mathrm{w} / \mathrm{v})$ oxytetracycline (Oxoid SR $073 \mathrm{~A}$ ), and the Enterobacteriaceae in Violet Red Bile Glucose agar, VRBG (Merck 10275), with a VRBG overlay.

\section{Characterisation of isolated lactic acid bacteria}

Isolates were made daily from appropriate MRS counting plates. Five representative colonies of $\mathrm{LAB}$ were isolated and subsequently purified on MRS agar. These were then stored at $-80^{\circ} \mathrm{C}$ in cryotubes containing $15 \%(\mathrm{w} / \mathrm{v})$ glycerol in MRS broth for later characterisation. Characterisation tests included Gram stain, morphology (by microscopic observations), catalase reaction, growth at $15^{\circ} \mathrm{C}$ and/or $45^{\circ} \mathrm{C}$, homo/heterofermentation and arginine hydrolysis. Confirmation of isolated lactic acid bacteria was obtained from established descriptions of non-sporing Gram-positive rods ${ }^{8}$ based on the utilisation of relevant carbohydrates on the API 50 CHL test strips (API System SA, Montalieu Vercieu, France).

\section{Crude protein content}

The crude protein content was determined using 


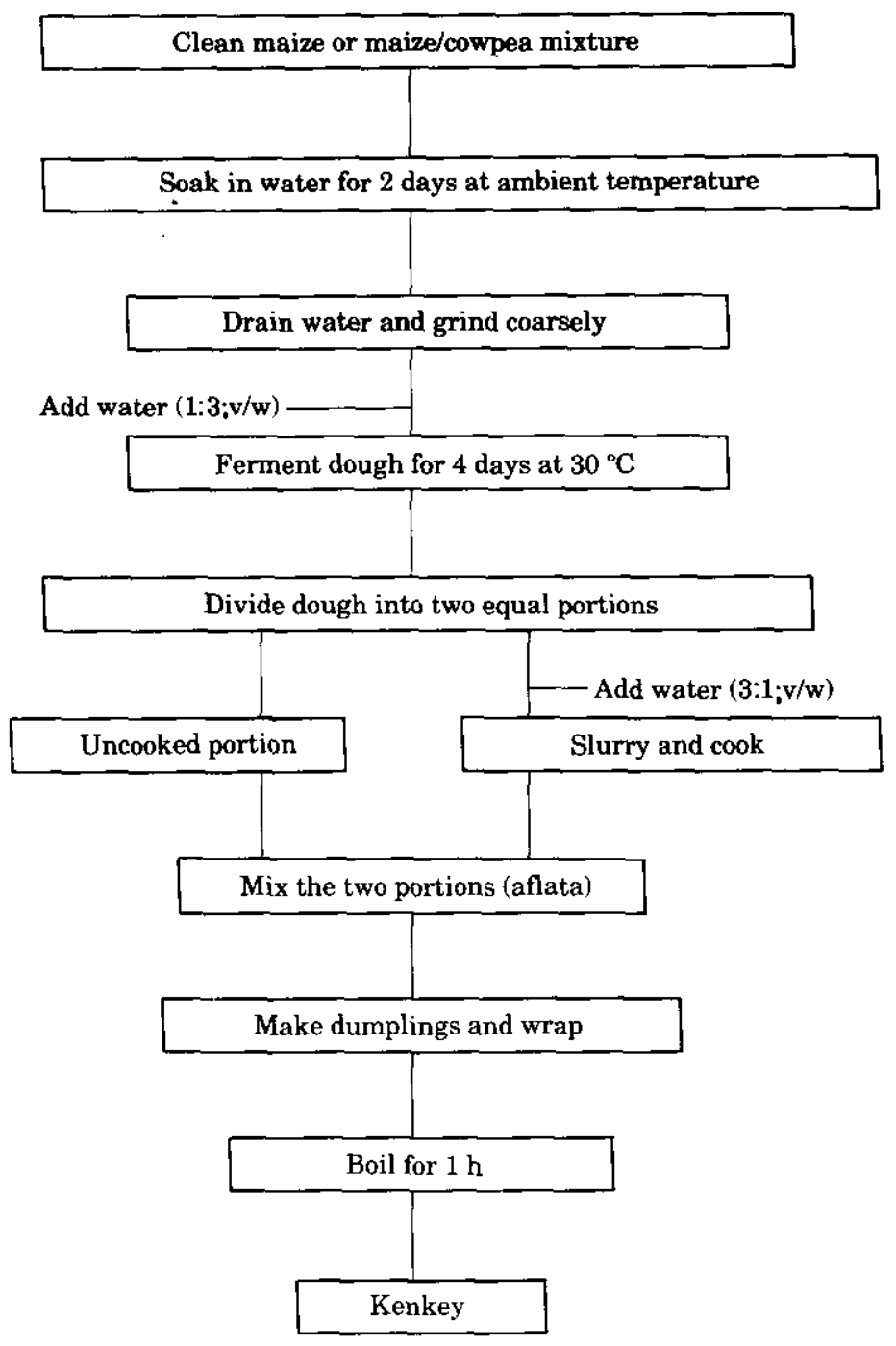

Figure 1 Laboratory method for kenkey production.

a semi-automated version of the micro-Kjeldahl method for nitrogen determination ${ }^{9}$. Experiments were done twice and all samples run in duplicate. The values for nitrogen concentration were converted to crude protcin content by multiplying by 5.26 for the maize ${ }^{10}$ and 5.46 for maize-cowpea blends $(5.26 \times 80 \%+6.25 \times 20 \%)$.

\section{Colour}

Colour parameters $L, a$ and $b$, representing whiteness, redness and yellowness, respectively, were measured using a DR LANGE Tricolor LFM3 Colorimeter (Hunterlab, 9529 Lee Highway, Fairfax, Virginia), calibrated with a standard white tile ( $L=88.20 ; a=-0 \cdot 96 ; b=-1 \cdot 69)$. Two measurements were made of the surface of each sample.

\section{Fracture stress}

Fracture stress was measured using an Overload Dynamics instrument (Marius Instruments, Utrecht, The Netherlands) having two plates, between which samples of standard cylindrical dimensions (length $3 \mathrm{~cm}$; diameter $2 \mathrm{~cm}$ ) were placed vertically and compressed at constant speed until fracture, and the fracture stress was calculated $^{i l}$. Dehulled cowpeas were used in supplemented kenkeys. 
Table I Fermentation profiles of all-maize and cowpea-supplemented maize doughs

\begin{tabular}{|c|c|c|c|c|c|}
\hline Dough $^{a}$ & $\mathrm{pH}$ & $\begin{array}{c}\text { Titratable } \\
\text { acidity } \\
(\%)^{b}\end{array}$ & $\begin{array}{l}\text { Lactic acid bacteria } \\
\left(\log _{10} \mathrm{cfu} / \mathrm{g}\right)\end{array}$ & $\begin{array}{c}\text { Yeasts } \\
\left(\log _{10} \mathrm{cfu} / \mathrm{g}\right)\end{array}$ & $\begin{array}{c}\text { Enterobacteriaceae } \\
\left(\log _{10} \mathrm{cfu} / \mathrm{g}\right)\end{array}$ \\
\hline $\mathbf{M}_{0}$ & $6 \cdot 02 a$ & 0.49 & $6 \cdot 72$ & $4 \cdot 36$ & 6.53 \\
\hline $\mathrm{M}_{1}$ & $4 \cdot 00$ & 0.97 & 8.09 & $<1 \cdot 70$ & $<1 \cdot 70$ \\
\hline $\mathbf{M}_{2}$ & $3.86 b$ & $1 \cdot 11$ & $8 \cdot 01$ & $<1 \cdot 70$ & $<1.70$ \\
\hline $\mathrm{M}_{3}$ & $4 \cdot 05 c$ & $1 \cdot 15$ & 7.97 & $<1 \cdot 70$ & $<1 \cdot 70$ \\
\hline $\mathrm{M}_{4}$ & $4.07 c$ & $1 \cdot 12 a$ & $7 \cdot 93 a$ & $<1.70$ & $<1 \cdot 70$ \\
\hline $\mathrm{Mw}_{0}$ & $5.87 a$ & 0.49 & $6 \cdot 05$ & $4 \cdot 79$ & $8 \cdot 86$ \\
\hline $\mathrm{Mw}_{1}$ & $4 \cdot 19$ & $I \cdot 3]$ & $8 \cdot 17$ & $<1 \cdot 70$ & $<1 \cdot 70$ \\
\hline $\mathrm{Mw}_{2}$ & $4 \cdot 11$ & $1 \cdot 46$ & $8 \cdot 00$ & $<1.70$ & $<1 \cdot 70$ \\
\hline $\mathrm{Mw}_{3}$ & $4 \cdot 07 c$ & $1 \cdot 55$ & $7 \cdot 94$ & $<1 \cdot 70$ & $<1 \cdot 70$ \\
\hline $\mathrm{Mw}_{4}$ & $4 \cdot 08 c$ & $1.57 b$ & $7 \cdot 93 a$ & $<1 \cdot 70$ & $<1 \cdot 70$ \\
\hline $\mathrm{Mr}_{0}$ & $6 \cdot 65 d$ & $0 \cdot 32$ & $7 \cdot 86$ & $4 \cdot 6 I$ & $8 \cdot 62$ \\
\hline $\mathrm{Mr}_{1}$ & $4 \cdot 31$ & $1 \cdot 32$ & $8 \cdot 34$ & $<1 \cdot 70$ & $<1 \cdot 70$ \\
\hline $\mathrm{Mr}_{2}$ & $4 \cdot 11$ & $\mathrm{I} \cdot 58$ & $8 \cdot 52$ & $<1 \cdot 70$ & $<1 \cdot 70$ \\
\hline $\mathrm{Mr}_{3}$ & $4.07 c$ & 1.67 & $8 \cdot 13$ & $<1 \cdot 70$ & $<1 \cdot 70$ \\
\hline $\mathrm{Mr}_{4}$ & $4 \cdot 08 c$ & $1 \cdot 73 c$ & $8 \cdot 07 a$ & $<1 \cdot 70$ & $<\mathrm{l} \cdot 70$ \\
\hline
\end{tabular}

Sample codes: $\mathrm{M}=100 \%$ maize; $\mathrm{Mw}=80 \%$ maize $+20 \%$ white cowpea; $\mathrm{Mr}=80 \%$ maize $+20 \%$ red cowpea; subscripts $(0,1,2,3,4)$ indicate fermentation time (days).

${ }^{b}$ Expressed as per cent lactic acid (w/w).

$a, b, c, t^{\prime}$ Values in the same column, with the same letter, are not significantly different $(P<0 \cdot 05)$.

\section{Product evaluation}

An untrained five-member panel of native Ghanaians (three males and two females, aged between 28 and 40 years) familiar with traditional kenkey was asked to evaluate the control and supplemented products on the basis of their sourness (taste), smell, texture, colour, doneness (degree of cooking) and hardness. This was done by individual structured interview, followed by group discussion. Each panellist was asked to sample the product and formulate how the supplemented kenkey compared with the all-maize traditional kenkey with respect to the above criteria. Each panellist was advised to draw from his or her experience as a traditional kenkey consumer. Individual comments were compared and the group discussion that followed was aimed at reaching a general consensus on the potential acceptability of the new product and recommendations on the possible improvement of the less-acceptable parameters.

\section{RESULTS AND DISCUSSION}

In our experiments to study lactic acid fermentation in kenkey doughs (Table I), the pH decreased and the titratable acidity increased as the lactic acid bacteria (LAB) count increased. LAB counts exceeded $10^{8} / \mathrm{ml}$ after only 24 -h fermentation. Further incubation led to a slight fall in $\mathrm{LAB}$ counts. Where yeasts occurred, lower counts $\left(<10^{5}\right)$ than LAB were often noticed. Yeast counts declined sharply with the rapid decrease in $\mathrm{pH}$. The Enterobacteriaceae counts also fell rapidly to below detection level as a result of acid production by the $\mathrm{LAB}^{12}$. Some authors ${ }^{13}$ believe that other substances (e.g. bacteriocins) produced by the dominating LAB may contribute to the disappearance of Enterobacteriaceae.

Table I confirms the trend observed by previous authors ${ }^{14}$ investigating the changes in $\mathrm{pH}$ and titratable acidity during the natural fermentation of cereals and legumes. They reported an optimum fermentation period of 2 and 3-4 days at $30^{\circ} \mathrm{C}$ for cereals and legumes, respectively. The $\mathrm{pH}$ of all-maize dough $\left(\mathbf{M}_{0}\right)$ fell from 6.02 to 3.86 in just 2 days, whereas that of supplemented doughs $\left(\mathrm{Mw}_{0}\right.$ and $\left.\mathrm{Mr}_{0}\right)$ required a further day to reach its lowest value of $4 \cdot 07$. After 4 days of incubation, the $\mathrm{pH}$ of all three doughs stabilised at 4.08 . The higher titratable acidity values obtained for supplemented doughs could be attributed to the high buffering capacity of the medium due to the higher content of proteins and amino acids ${ }^{15,16}$. The addition of $20 \%$ cowpeas, therefore, did not hinder proper dough fermentation, although a longer time was required for 
Table II Crude protein contents of doughs of maize and maize-cowpea blends

\begin{tabular}{lc}
\hline Dough $^{a}$ & $\begin{array}{c}\text { Crude protein content } \\
(\% ; \mathrm{w} / \mathrm{w} ; \text { dry matter })^{\mathrm{b}}\end{array}$ \\
\hline $\mathrm{M}_{0}$ & $10 \cdot 41 \pm 0 \cdot 49$ \\
$\mathrm{M}_{4}$ & $10 \cdot 80 \pm 0 \cdot 32$ \\
$\mathrm{Mw}_{0}$ & $12 \cdot 57 \pm 0.21$ \\
$\mathrm{Mw}_{4}$ & $12 \cdot 99 \pm 0.21$ \\
$\mathrm{Mr}_{0}$ & $13.51 \pm 0.20$ \\
$\mathrm{Mr}_{4}$ & $13.89 \pm 0.24$ \\
\hline
\end{tabular}

"Sec Table 1 for meaning of sample codes.

b Mean \pm s.D.; $n=4$.

acidification to stabilise. Two and 3 days of fermentation were sufficient to lower the $\mathrm{pH}$ of all-maize and cowpea-supplemented doughs, respectively, to the inhibitory $\mathrm{pH}$ range $(3 \cdot 6-4 \cdot 1)$ for food poisoning bacteria reported by Hamad and Fields ${ }^{17}$. These authors did not specify lactic acid as responsible for lowering the $\mathrm{pH}$ to this inhibitory range, however.

Tests identified Lactobacillus plantarum, L. confusus, L. brevis and Pediococcus pentosaceus as the main lactic acid bacteria present in the fermenting doughs. In the case of doughs $\mathrm{M}_{0}$ and $\mathrm{Mw}_{0}, L$. confusus was found to dominate the earlier stages of fermentation $\left(d_{0}\right)$. These were later replaced by Pediococcus spp. and L. plantarum for $\mathrm{M}_{1-4}$ and $\mathrm{Mw}_{1.4}$, respectively. The pattern was one of acidsensitive heterofermentors being succeeded by more acid-tolerant homofermentors. This was in line with the decrease in $\mathrm{pH}$ and the increase in titratable acidity (Table $\mathrm{I}$ ) as fermentation progressed.

The pattern was less clear for $\mathrm{Mr}_{0 \cdot 4}$, in which $L$. plantarum, $L$. confusus and Pediococcus spp. were present in similar proportions throughout the 4 days' fermentation.

The addition of $20 \%$ red and $20 \%$ white cowpea resulted in increases in crude protein contents of $29 \cdot 2 \%$ and $20.5 \%$, respectively, for the supplemented products. The values for crude protein content shown in Table II are comparable with those reported earlier ${ }^{5}$ for ogi fortified with cowpeas. With regard to the average essential amino acid contents of maize ${ }^{18}$ and cowpea ${ }^{6}$, these values represent, respectively, $76.3,15.6$ and $26.8 \%$ increases in lysine, methionine and tryptophan in maize-red cowpea blends and $65.3,8.2$ and $19.5 \%$ increases in lysine, methionine and tryptophan, respectively, in maize-white cowpea blends.

The addition of wholegrain cowpea reduced the
Table III Colour parameters of all-maize and cowpcasupplemented kenkey (Hunter L, $a$ and $b$ values)

\begin{tabular}{|c|c|c|c|}
\hline Kenkey ${ }^{a}$ & $\begin{array}{c}L \\
(\text { mcan } \pm \text { s.D. })\end{array}$ & $a$ & $b$ \\
\hline $\mathrm{M}_{4} \mathrm{C}_{1}$ & $66 \cdot 89 \pm 0.46$ & $0.10 \pm 0.74$ & $16.48 \pm 1.37$ \\
\hline $\mathrm{Mw}_{4} \mathrm{C}_{1}$ & $58 \cdot 86 \pm 2 \cdot 02$ & $3 \cdot 00 \pm 1 \cdot 25$ & $13 \cdot 67 \pm 2 \cdot 14$ \\
\hline $\mathrm{Mw}_{4} \mathrm{C}_{1}^{\mathrm{b}}$ & $61.09 \pm 1.45$ & $0.44 \pm 0.08$ & $15 \cdot 72 \pm 0 \cdot 36$ \\
\hline $\mathrm{Mr}_{4} \mathrm{C}_{1}$ & $49 \cdot 70 \pm 3 \cdot 28$ & $6 \cdot 30 \pm 1 \cdot 13$ & $10 \cdot 86 \pm 1 \cdot 37$ \\
\hline $\mathrm{Mr}_{4} \mathrm{C}_{\mathrm{l}}^{1}$ & $54 \cdot 03 \pm 1 \cdot 87$ & $8.07 \pm 0.25$ & $12 \cdot 19 \pm 0 \cdot 33$ \\
\hline
\end{tabular}

a Sample codes in addition to those in Table I; $\mathrm{C}=$ cooked, with subscript cooking time (hours).

h Dehulled cowpeas.

whitenesss of the product (Table III). This was more pronounced with the addition of red cowpeas where the colour change was noticeable. Dehulling the cowpeas improved the colour visibly even though the Hunterlab $L$ values were still very much lower than for all-maize kenkey. Traditional kenkey is usually wrapped in either banana leaves (fanti kenkey) or corn sheaths (ga kenkey), which results in a slight browning of the surface of the product after cooking. This does not seem to be of concern to the consumer, hence a reduction in whiteness by white cowpea is not expected to be a major setback. Red cowpea will, however, require dehulling to prevent the final product becoming brown. Other authors ${ }^{3}$ used a Hunterlab Model D25D Color Meter, calibrated with a standardised white tile ( $L=93.6, a=0.7$ and $b=0.2)$, and obtained $L, a$ and $b$ values of $76.94 \pm 0 \cdot 14$, $-1 \cdot 14 \pm 0.06$ and $10.55 \pm 0 \cdot 23$, respectively, for traditional fermented maize doughs from Ghana. The differences between those $L, a$ and $b$ values and the values reported here may be due to the use of different standardisation constants. Also, those authors referred to fermented dough and not to the cooked product of fermented doughs used in this project.

Fracture experiments were conducted on kenkey stored at room temperature for 1, 24 and $72 \mathrm{~h}$. The moisture contents were maintained by storing samples well wrapped up with aluminium foil in a closed bucket. Table IV shows that fracture stress $\left(\alpha_{f}\right)$ increased with increasing cowpea levels. This may be due to the fact that cowpea supplementation results in a more homogeneous product, which is less prone to breakage than the traditional all-maize kenkey. In the traditional kenkey, intact maize hulls form areas of local stress concentration, which makes the product more prone to fracturing ${ }^{19}$. In addition, 
Table IV Effect of cowpca level and storage on hardness of kenkey at constant moisture content

\begin{tabular}{|c|c|c|c|c|}
\hline Kenkey ${ }^{a}$ & $\begin{array}{l}\text { Cowpea } \\
\text { level }(\%)\end{array}$ & $\begin{array}{l}\text { Storage time } \\
\text { (h) }\end{array}$ & $\begin{array}{l}\text { Moisture content } \\
(\% ; w / w)\end{array}$ & $\begin{array}{l}\text { Stress at fracture } \\
\left(\times 10^{3} \mathrm{Nm}^{-2}\right)^{b}\end{array}$ \\
\hline $\mathrm{M}_{4} \mathrm{C}_{3}$ & 0 & $\begin{array}{r}1 \\
24 \\
72\end{array}$ & $\begin{array}{l}64 \\
63 \\
63\end{array}$ & $\begin{array}{l}2 \cdot 40 \pm 0 \cdot 10 \\
4 \cdot 50 \pm 0 \cdot 20 \\
4 \cdot 20 \pm 0 \cdot 20\end{array}$ \\
\hline $\mathrm{Mw}_{4} \mathrm{C}_{1}$ & 10 & $\begin{array}{r}1 \\
24 \\
72\end{array}$ & $\begin{array}{l}63 \\
63 \\
62\end{array}$ & $\begin{array}{l}3 \cdot 40 \pm 0 \cdot 30 \\
6 \cdot 30 \pm 0 \cdot 10 \\
6 \cdot 50 \pm 0 \cdot 10\end{array}$ \\
\hline $\mathrm{Mw}_{4} \mathrm{C}_{1}$ & 20 & $\begin{array}{r}1 \\
24 \\
72\end{array}$ & $\begin{array}{l}67 \\
63 \\
63\end{array}$ & $\begin{array}{l}3 \cdot 15 \pm 0 \cdot 10 \\
6 \cdot 35 \pm 0 \cdot 20 \\
6 \cdot 95 \pm 0 \cdot 60\end{array}$ \\
\hline $\mathrm{Mw}_{4} \mathrm{C}_{\mathrm{i}}$ & 30 & $\begin{array}{r}1 \\
24 \\
72\end{array}$ & $\begin{array}{l}63 \\
63 \\
63\end{array}$ & $\begin{array}{l}4 \cdot 30 \pm 0 \cdot 20 \\
8 \cdot 30 \pm 0 \cdot 10 \\
8 \cdot 10 \pm 0 \cdot 20\end{array}$ \\
\hline $\mathrm{Mw}_{4} \mathrm{C}_{1}$ & 50 & $\begin{array}{r}1 \\
24 \\
72\end{array}$ & $\begin{array}{l}65 \\
65 \\
66\end{array}$ & $\begin{array}{l}3 \cdot 20 \pm 0 \cdot 20 \\
8 \cdot 10 \pm 0 \cdot 10 \\
7 \cdot 90 \pm 0 \cdot 10\end{array}$ \\
\hline
\end{tabular}

a For abbreviation see Table I and Table III, with the exception that the level of cowpea substitution ranges from $0-50 \%$, as specified above.

b Mean \pm s.D.; $n=3$.

starch/protein interactions may contribute to the increased firmness of the product. Fracture stress also increased on storage of the product, the greatest increase occurring in the first $24 \mathrm{~h}$, during which fracture stress $\left(\alpha_{i}\right)$ values doubled. This may be attributable to a number of factors, amongst them setback and retrogradation of starch as the product cools ${ }^{20}$, resulting in a firmer product.

The sharp sour taste of properly fermented kenkey ${ }^{3}$ was detected in all samples by all panellists. None registered off-smells resulting from the addition of cowpeas. Kenkey made from mixtures of $80 \%$ maize and $20 \%$ wholegrain white or dehulled red cowpeas were preferred by all the panellists as these compared very well with the traditional product. Three male panellists also liked the kenkey supplemented with dehulled white cowpea, but the two female panellists thought it was smoother than the traditional product. Kenkey supplemented with wholegrain red cowpeas was rejected by all but one (male) of the panellists on account of its brown colour.

Although the results of product evaluation must be interpreted cautiously, they, nevertheless, place additional weight on the argument that traditional kenkey could be enriched with $20 \%(\mathrm{w} / \mathrm{w})$ cowpeas without necessarily affecting its basic physical and organoleptic properties. Large-scale product evaluation is required, however, to establish absolutely the degree of acceptability of cowpea-supplemented kenkey.

Previous reports on ccreal-legume mixtures ${ }^{6,21}$, and the results reported in this paper, suggest that cowpea could be used successfully to supplement traditional cereal-based products. This will undoubtedly go some way towards improving the protein requirements of people of a region where animal sources of protein are often too expensive to be afforded by many people.

\section{Acknowledgements}

We thank M. Aarntzen for her technical contribution. Financial support by the European Community (Contract no. TS2-0267-UK, "The evaluation and improvement of traditional fermented cereals and legumes in Ghana") is gratefully acknowledged.

\section{REFERENCES}

1. Muller, H.G. Ghana Journal of Agricultural Science 3 (1970) 187-191.

2. Muller, H.G. and Nyarko-Mensah, B. Journal of the Science of Food and Agriculture 23 (1972) 544-545.

3. Plahar, W.A. and Leung, H.K. Journal of the Science of Food and Agriculture 44 (1983) 407-411.

4. Akinrele, I.A. and Edwards, C.C.A. British Journal of Nutrition 26 (1971) 177-185. 
5. Akinyele, I.O. and Fasaye, O.A. Journal of Food Science $\mathbf{5 3}$ (1988) 1750-1755.

6. Bressani, R. in 'Cowpea Rescarch, Production and Utilization' (S.R. Singh, ed.) J. Wiley \& Sons, Chichester (1985) pp 353-359.

7. Nout, M.J.R., Beernink, G. and Bonants-van Laarhoven, T.M.G. International Journal of Food Microbiology 4 (1987) 293-301.

8. Kandler, O. and Weiss, $\mathrm{N}$. in 'Bergey's Manual of Systcmatic Bacteriology', Vol. 2 (P.H.A. Sneath, N.S. Mair, M.E. Sharpe and J. Holt, eds.) G. Williams \& Wilkins, Baltimore (1986) pp 1208-1234.

9. Roozen, J.P. and Van Boxtel, L. De Waren-Chemicus 9 (1979) 192-195.

10. Thomas, L.M. in "The Chemistry and Technology of Food Products', Vol. 1, 2nd edn (M.B. Jacobs, ed.) J. Wiley \& Sons, New York (1951) pp 139-220.

11. Van Vliet, T. Bulletin of the International Dairy Federation 268 (1991) 17-23.

12. Nout, M.J.R., Rombouts, F.M. and Hautvast, G.J. United Nations University Food and Nutrition Bulletin 11 (1989) 65-73.
13. Mensah, P., Tomkins, A.M., Drasar, B.S. and Harrison, T.J. Journal of Applied Bacteriology 70 (1991) 203-210.

14. Chavan, U.D., Chavan, J.K. and Kadam, S.S. Journal of Food Science 53 (1988) 1574-1575.

15. Banigo, E.O.I. and Muller, H.G. Canadian Institute of Food Science and Technology Joumal 5 (1972) 217-221.

16. Zamora, A.F. and Fields, M.L. Journal of Food Science 44 (1979) 234-236.

17. Hamad, A.M. and Fields, M.L. Jaurnal of Food Science 44 (1979) 456-459.

18. Salunkhe, D.K., Chavan, J.K. and Kadam, S.S. 'Postharvest Biotechnology of Cereals', Chapter 6, CRC Press, Boca Raton, Florida (1985) pp 93-111.

19. Luyten, H. PhD thesis, Agricultural University, Wageningen, Department of Food Science, The Netherlands (1988) pp 142-151.

20. Bean, M.M. and Setser, C.S. in 'Food Theory and Applications', 2nd edn (J. Bowers, ed.) Macmillan, New York (1992) pp 69-198.

21. Bressani, R. and Scrimshaw, N.S. National Academy of Science Washington, D.C., Pub. 843 (1961) 35-48. 